\title{
Brief Discussion on Art Expression in Museum Exhibit Display under Social Significance
}

\author{
Jianzhou Lu \\ Zhengzhou University of Light Industry \\ Zhengzhou, China
}

\begin{abstract}
How to make art into lifestyle and deepened and what kind of expression form shall be adopted become the target for all under multiple cultural content of contemporary society. However, as the audience aesthetic is gradually increasing with diversity today, we shall begin research on art form of display design or exhibit display, as well as deepening expression of display exhibit cultural idea from many aspects. Single form could not meet spiritual requirements of the public already. Contemporary display and exhibit effect is depended on the level of display art design to a great extent.
\end{abstract}

Keywords-museum exhibit; exhibit display; art principle; Social significance of exhibit.

\section{CONDITIONS OF MUSEUM EXHIBITS DISPLAYING}

Museum undertaking developing rapidly in China and expression form of exhibit display are unable to achieve balanced development. People pay more attention to the exhibit itself rather than "interactivity" between the audience and exhibit, so that the exhibits displaying becomes rather simple and short of persuasion. Then it further weakens the meaning and value of exhibit and museum existence.

\section{TRADITIONAL VIEWPOINT: IT RATHER LAGS BEHIND COMPARED DISPLAY WITH ITS OWN THEORY}

With utterly arrival of information age, information technology and application of new technology can be found everywhere. But the museum may be stay in more conservative phase as a public place to display actual objects (historical relics or art). And the application of art principle also remain the level of protecting security of the product itself in exhibit display, but the deepening exhibit meaning is placed at the secondary position. In most of museum, exhibit display has such display form as exhibit is the center, while it has certain careless mistake and insufficiency in making the audience accurately understand cultural background or Social significance of the product from the view of exhibit display. It could not demonstrate cultural context of historical relics regardless of some hardware expression such as light use, or placing viewpoint; even it is rather simpler in security issue of exhibit display; it' $\mathrm{s}$ rare to get people satisfied slightly to activities between the audience and exhibit, as well as participation.
It could not reach harmonious state in organic fusion in application of new science and technology as well as display of art design principle, and the mutual combination is not close enough. It also could not become the organic carrier for historical relics display whether in view of the museum as an extracurricular auxiliary place for fine arts education, or in expression of exhibit displaying artistic conception. The use of artistic principle does not function as powerful relying in science and technology of display design, so it loses the social educational function of historical relics.

Science and technology shall be relied on in display design of museum exhibit. It could only give full play of social function of the exhibits by using certain artistic principle based on protection of exhibit security, such as, confidence in the theme of the exhibit display, popular art form, more perfect image of exhibit display, relatively rigorous art structure of exhibit display, creation of a specific environment, security of exhibit display, and economic rationality of exhibit display. All these are necessary for culturing the conception of exhibit display, creating real display environment and establish "returning feeling" that the audience have to the product. Therefore, the exhibit display table has become one of the art reference standards in combination form, scientificity of form existence, economic properties and security.

\section{A. Beauty in Form}

Museum bears corresponding function to serve for the public as a part of public cultural space. It absolutely shall be designed in a form acceptable to the public or a popular form in display art of the exhibit. However, art principle established in practice procedure of art in the long run provides relevant reference for art display.

At first, museum as a public cultural place, accepting object of the exhibit makes us to consider the public aesthetic tendency, and art display form appealing to both cultured and popular tastes is more acceptable for the public aesthetic and much closer to visual psychology of the public, moreover, it could generate more resonation among them. It could better function as Social significance of exhibit display and better display the social function of museum existence as it does so.

Secondly, we could take modern science and technology as carrier in display aspect of beauty in form to highlight 
artistic personality or social significance of the exhibit itself. It shall be developed from full monomer column of physical object to the direction of integrating environment, to completely highlight exhibit' s regional and ethnic factors, so as to make the exhibit more easily accepted by the public, also make the public participating into it as much as possible.

We could refer to digital art expression means in some contemporary art display and combine with the structure of some modern design to show era cultural context of the product.

\section{B. Preciseness of Display}

We shall pay attention to its proper expression form without art form. We could not distort the social significance of art itself due to the pursuit of art expression. We could not specify the cultural meaning of art because the preciseness of expression form cannot be ignored.

In the expression form of some museum exhibit display, the connotation of exhibit itself is weakened and even ignored in order to pursue external form of the exhibit itself. Therefore, we shall consider mutual relations and specific cultural belonging in mutual combination of the exhibit and environmental creation of the product, so as to form organic combinational form.

We can see the real model reconstruction in art display way of Dynasty Xia building model in a museum in Henan Province, and add with vegetation to show the true form of Dynasty Shang dwelling house and the environment it locates, thus it brings the audience to Xia culture at the beginning of civilization.

\section{Economic Factor}

Exhibit display is different from pure academic performance in the contemporary museum exhibit display, and it' s not a pure expression of plastic arts of course. From the perspective of the exhibit display design, display design may have double meanings of economic performance and cultural features from the date of birth based on its features.

Economic factor absolutely will become an issue to be considered in design of all industries as one of the design principle, and there is no exception for economic performance of display design itself which will definitely become an aspect we focus. It has become development tendency of the times to advocate display form with economical spirit based on fully displaying cultural connotation of the exhibit and security of exhibit display. It also became the design theme of the current times.

\section{Security}

Display security is another principle to be followed in exhibit display. Of course, security is not unilateral but twoway nature. It not only includes security of exhibit when displayed and it also shall consider security of viewers. It shall fully take security of both sides into account while form beauty is not lost, and social significance and cultural connotation behind the exhibit are not insulted. In doing so, it could be said to be a well-done by following good example.

In terms of security of exhibits, it shall fully embody the scientificity. On the one hand, it shall fully ensure "authenticity" of the exhibit which means not lose its original image from the microclimate where the exhibit locates, so that viewers could see real color and texture. On the other hand, the museum could not ignore security protection of displayed exhibit from large environment of exhibit protection.

Application of modern science and technology becomes the effective carrier form carrier. Temperature adjustment, rationality of humidity and lamplight illume could help prolong the own life of cultural relic from microclimate, all of which depend on scientific ontology; anti-theft, fire prevention and shockproof become another concerns for security from large environment.

Preparation for museum display exhibit security is a guarantee for external display and excellent art form expression. Security of external form shall be coordinated and coexisted with beauty in form. The use of modern material and modern science and technology provide more possibilities for the pubic and enjoy "real art".

\section{RETURNING - CREATION OF ARTISTIC CONCEPTION}

Creation of artistic conception is the cultural demonstration to exhibit display, and it also the transcendence of time and space, it even refers to returning for enjoyers to exhibit reality. The results can be seen here as enjoyers who accepting artistic advocacy extend the artistic conception and idea. The reference and absorption of idea form and the use of sound, light and electricity as well as scientific and technological means are the support of creation of artistic conception.

Display design which is superficial and stresses on external form loses its depth. That it' s unable to correctly demonstrate personal feature and cultural meaning of the exhibits becomes the current malpractice. It' $\mathrm{s}$ also an issue worthy of our consideration that Chinese traditional culture spirit is applied in museum design. "Artistic conception theory" in Chinese traditional culture provides referable basis for the audience to have feeling on realistic returning in display design. Because it stressed on creation of artistic conception in display design, it not only solved the problems to accurately delivery cultural artistic conception of exhibit displayed, but also create a scene of "returning style". It can make the audience feel the power of Chinese traditional culture while understanding deep culture behind the product.

Creation of artistic conception could not only embody specific personality of the product displayed, but also unlimitedly extend limited display space. It uses thousandmile art thoughts to conceive a scene with interest and reality. Unlimited space is expressed by limited space. Art 
atmosphere beyond time is the idea base to create reality of museum exhibit display.

Speaking of external material medium, application of acoustics and lamplight in modern science and technology also becomes the effective carrier of creation of artistic conception. In terms of display design, we could use light source to foil display product atmosphere, so as to reach the "truth" . Regarding use of light source, lamplight illume adopted by most museum exhibit display in China at present has simple effect and single form which easily make viewers have feeling of fatigue. It' $s$ can neither fully stimulate visual exciting nor make contribution for creating cultural atmosphere of display product. Furthermore, it's unmatched with increasingly growing museum course in China. Therefore, we should rethink the improvement of environmental lamplight, so as to make continuous perfection and truly "add luster" for exhibit display.

The light is also an important support for the whole display space as the visual medium to improve image of display product. If natural light has organic combination with manual light, it has significant meaning in shaping product image and creating overall atmosphere of the museum. Because it could not only highlight external form beauty of the product to make the audience understand external form of the product, but also further devote power to create cultural conception of the product. Then it will truly achieve social significance of the museum. Under precondition of scientific utilization of lamplight, that artificial illumination has suitable grasp and proper viewpoint for display product makes the display product more vital and more display effect, and rich in display of original appearance; it brings out the best in each other for exhibit display by natural lamplight replacing artificial lamplight to adjust and control the environment with support of artificial illumination.

\section{CONCLUSION}

In multicultural coexistence today, the meaning for the museum or gallery is not for storing relics of art, but shall use the museum exhibits provide spiritual food to the public on the basis of playing its social significance in the case of the public increasingly rich spiritual life.

\section{REFERENCES}

[1] Huang Jiancheng Space Display Design, Peking University Press, 2007

[2] Li Hua Brief Introduction to Display Design Art of the Museum, scientific and technological infor mation, 2008. 